\title{
Implementasi Sensor Kinect pada Mobile Robot untuk Inspeksi Objek yang Mengandung Bahan Kimia
}

\author{
Muhammad Iqbal Fahmi, Muhammad Rivai, dan Hendra Kusuma \\ Departemen Teknik Elektro, Fakultas Teknologi Elektro, Institut Teknologi Sepuluh Nopember (ITS) \\ e-mail: hendra@ee.its.ac.id
}

\begin{abstract}
Abstrak-Adanya teror bom yang terjadi saat ini dengan cara meletakkan barang-barang mencurigakan di lokasi tertentu masih banyak terjadi. Metode saat ini untuk menjinakkan bom menggunakan rompi anti-peledak khusus masih merupakan risiko yang berbahaya. Pada penelitian ini telah dibuat sebuah Mobile Robot yang dilengkapi Sensor Kinect, Modul Sensor Gas MQ-5, Metode HSV dan Image Proccesing. Pada pengujian yang mengimplementasi sensor kinect pada mobile robot untuk inspeksi warna objek target dan dilengkapi sensor gas MQ-5 untuk melakukan aktifitas pemetaan terhadap gas Iso-Butane pada suatu lokasi objek. Hasil percobaan image proccesing dengan kamera sensor kinect ketika mendapatkan nilai objek warna hijau dengan metode HSV adalah hue 29 - 84, saturation 86 - 255, value 6 - 255 dengan percahayaan ruangan 2000 lux, kesalahan nilai warna objek hijau dengan percahayaan ruangan 80 lux mengakibatkan mendeteksi warna objek kuning. Pada hasil pemetaan sensor gas menunjukan arah dan kecepatan angin melebihi 5 km/jam mempengaruhi kenaikan dan penurunan nilai pembacaan kadar gas, sedangkan ketika pengukuran jarak menggunakan depth sensor kinect antara jarak mobile robot dengan objek minimal $40 \mathrm{~cm}-400 \mathrm{~cm}$.
\end{abstract}

Kata Kunci-Metode HSV, Sensor Kinect, Sensor MQ-5.

\section{PENDAHULUAN}

$\mathrm{P}$ ADA era perkembangan teknologi saat ini tingkat kriminalitas dan terorisme semakin meningkat. Pelaku terorisme menggunakan kemajuan teknologi untuk mengembangkan aksi teror seperti pengeboman. Berbagai macam bom yang dirakit banyak menggunakan bahan kimia berbahaya. Bahan kimia yang membentuk zat berbahaya sangat mudah didapat dan telah digunakan pada kasus terorisme di berbagai negara.

Berdasarkan data yang diperoleh dari sebuah sumber pada bulan September 2015 menunjukkan bahwa penindakan yang dilakukan kepada pelaku tindak pidana terorisme sampai dengan September 2015 berjumlah 1.143 orang. Dari jumlah tersebut yang sudah bebas sebanyak 501 orang, yang masih menjalani hukuman sebanyak 328 orang, dan tersangka yang dikembalikan kepada keluarga sebanyak 98 orang. Selain itu ada tersangka yang meninggal dunia sebanyak 127 orang, meninggal dunia karena penegakkan hukum sebanyak 108, meninggal dunia karena eksekusi mati sebanyak 3 orang, dan mati karena bunuh diri sebanyak 16 orang [1].

Sebagai upaya untuk mencegah terjadi kecelakaan dalam kegiatan penjinakan bom salah satu kemajuan teknologi terbaru saat ini adalah penggunaan mobile robot yang mampu menggantikan tugas manusia dalam melakukan pekerjaan yang berbahaya, dalam bidang keamanan dengan tujuan untuk mendeteksi suatu objek yang mengandung bahan kimia dari benda yang mencurigakan, sehingga resiko terjadinya kecelakan pada manusia dapat berkurang.

Mobile robot yang sudah ada memiliki beberapa kelemahan dalam hal keakuratan mendekati target dan beberapa robot penjinak bom belum terpasang kamera yang dapat berfungsi sabagai sensor untuk mendekati target [2]. Belum dilengkapi sensor gas semikonduktor untuk menginspeksi kandungan gas pada target.

Menyadari hal tersebut maka diusulkan sebuah mobile robot yang dapat berjalan diarea yang datar, mendekati target objek menggunakan sensor kinect dan mendeteksi kandung kadar gas iso-butane dengan sensor gas MQ-5.

\section{DASAR TEORI}

\section{A. Senssor Kinect}

Sensor Kinect adalah sebuah aksesoris untuk platform game konsol Xbox 360. Kinect merupakan sebuah motion sensing unit device yang dikembangkan untuk mengintegrasikan gerak tubuh manusia. Kinect memiliki sensor-sensor yang terhubung dengan motorized pivot based. Perangkat ini memiliki kamera RGB, depth sensor, dan multiarray microphone yang terdapat pada Gambar 1. Dengan sensor-sensor tersebut Kinect dapat menyajikan kemampuan melakukan full-body 3D motion capture, facial recognition, dan voice recognition. Kinect memiliki performasi yang baik, dimensi yang kecil, open source libraries yang mampu membuat kinect digunakan pada beberapa platform $O S$ (Windows, Linux, dan Mac), serta memiliki harga yang cukup murah [3]. Sensor Microsoft Kinect mampu mengeluarkan keluaran video dengan framerate $60 \mathrm{~Hz}$ sebagai kombinasi dari dua sensor yang berbeda, pertama dihasilkan oleh kamera RGB dengan resolusi 8 bit VGA (640x480 pixel) dengan Bayer Color Filter, yang kedua dihasilkan oleh monochrome depth sensor dengan resolusi yang sama, dan 2048 tingkat sensitivitas (11 bit) [3].

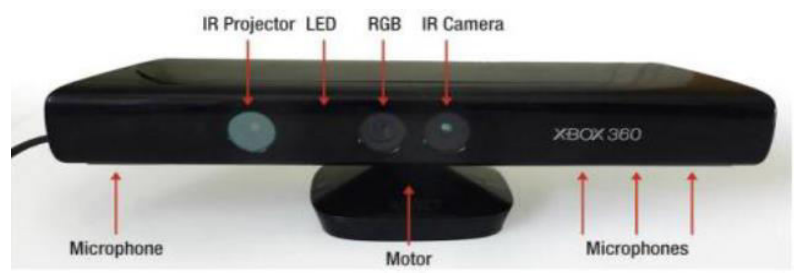

Gambar 1. Komponen- komponen dari sensor Kinect [3]. 


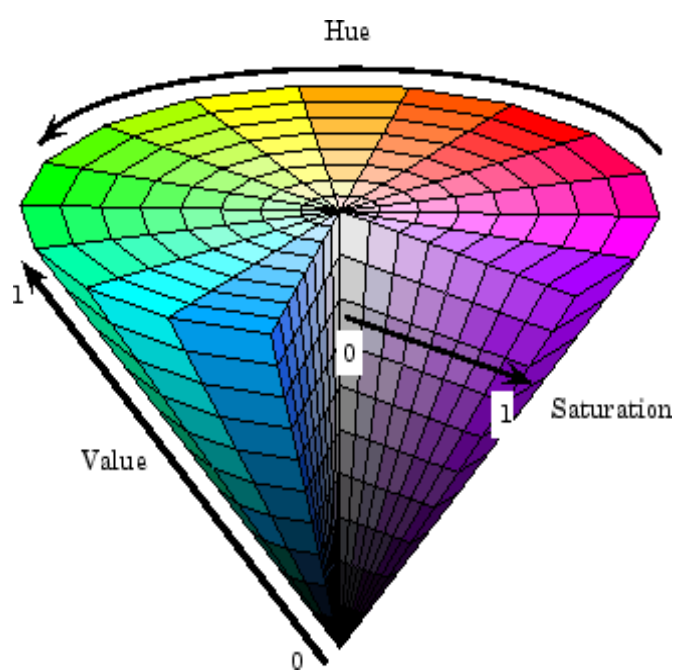

Gambar 2. Model ruang warna HSV [3].

\section{B. Citra Dengan Ruang Warna HSV}

HSV merupakan ruang warna yang merepresentasikan warna seperti yang dilihat oleh mata manusia. $\mathrm{H}$ berasal dari kata "hue", yaitu sesuatu yang biasa disebut oleh sebagian orang sebagai warna, misalnya perbedaan antara warna merah dan merah muda. S berasal dari "saturation" yang menunjukkan jumlah warna yang ada. V berasal dari "value" yang menunjukkan jumlah cahaya yang ada, misalnya perbedaan antara merah gelap dengan merah cerah [4]. Model ruang warna HSV ditunjukkan oleh Gambar 2.

\section{Filter Dilatasi dan Erosi}

Dilatasi adalah proses penambahan pixel disekitar area pada gambar objek. Sedangakan erosi adalah proses pemindahan pixel untuk diletakkan disekitar objek. Jumlah pixel yang ditambahkan dan dipindahkan tergantung pada ukuran dan bentuk gambar dari struktur elemen yang digunakan pada image prosesing. Ada dilatasi dan erosi memiliki aturan :

1. Dilatasi : Nilai keluaran pixel adalah maksimum pada semua nilai yang masukan. Pada gambar biner, apabila nilai masukan 1, maka hasil keluarannya juga 1[4]. Yang tertera pada Gambar 3.

2. Erosi : Nilai output pixel adalah minimum pada semua nilai yang masukan. Pada gambar biner, apabila nilai masukan 0, maka hasil keluarannya juga 0 [4]. Yang tertera pada Gambar 4.

Contoh metode dilatasi dan erosi pada biner :

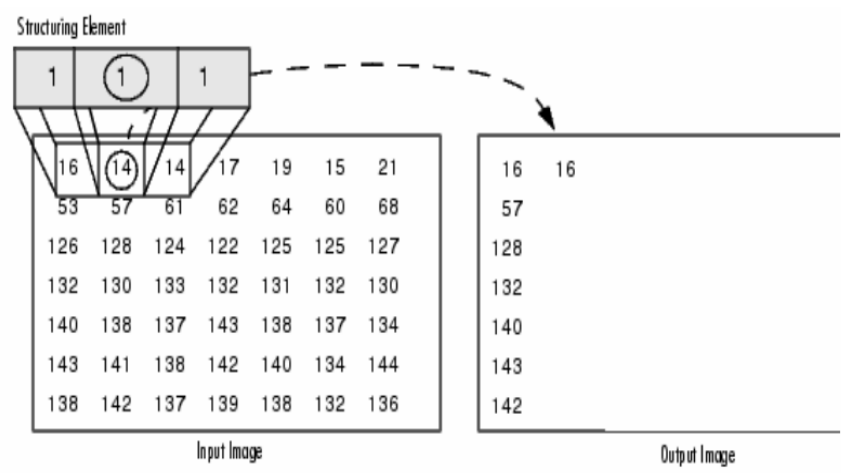

Gambar 3. Dilatasi pada grayscale image [4].

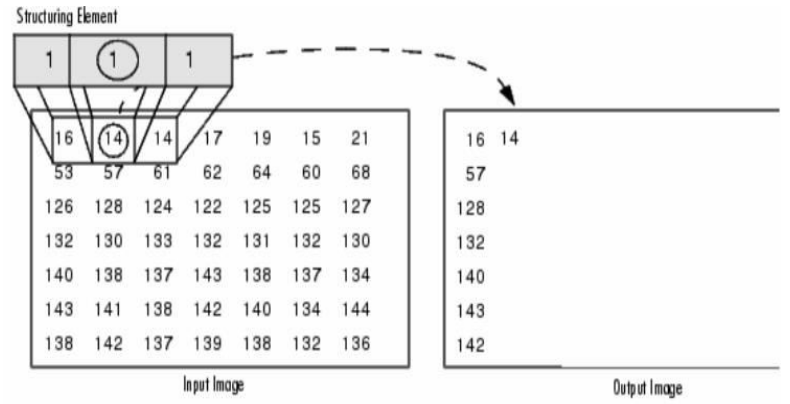

Gambar 4 Erosi pada grayscale image [4].
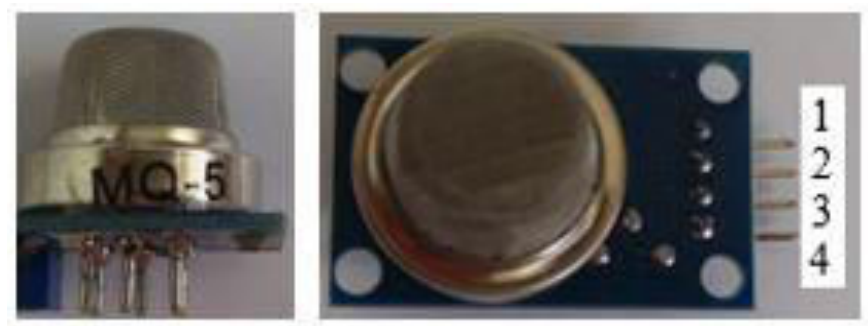

Gambar 5. (a) Sensor MQ-5, dan (b) Modul sensor MQ-5.

\section{Sensor $M Q-5$}

Pada Gambar 5 adalah jenis modul sensor gas MQ-5 dengan keterangan pada Tabel 1 . Sensor ini memang tidak sesensitif sensor gas lainnya, namun kelebihannya adalah sifatnya yang universal yang mampu mendeteksi tipe gas yang lebih luas. Pada Gambar 5.a di atas ini merupakan gambar sensor MQ-5 sedangkan Gambar 5.b. merupakan gambar sensor MQ-5 yang telah dikemas menjadi sebuah modul. Sensor MQ-5 adalah sensor universal yang mampu mendeteksi berbagai jenis gas seperti hidrogen (H2), karbon monoksida $(\mathrm{CO})$, metana $(\mathrm{CH} 4)$, etanol $(\mathrm{CH} 3 \mathrm{CH} 2 \mathrm{OH})$, propana $(\mathrm{C} 3 \mathrm{H} 8)$, butane (C4H10), dan gas hidrokarbon lainnya.

Keterangan :

Rs : Resistansi sensor pada konsentrasi tertentu

Ro : Resistansi sensor pada 1000 ppm H2 udara terbuka

Gambar 6 merepresentasikan karakteristik sensitifitas dari sensor MQ-5 dan karakteristik ketergantungan temperatur dan kelembaban. Sumbu-y mengindikasikan sebagai rasio resistansi sensor yang ditentukan. Merupakan perbandingan resistansi (Rs/Ro) di mana Rs merupakan resistansi sensor ketika mendeteksi gas, dan Ro merupakan resistansi sensor pada udara bersih.

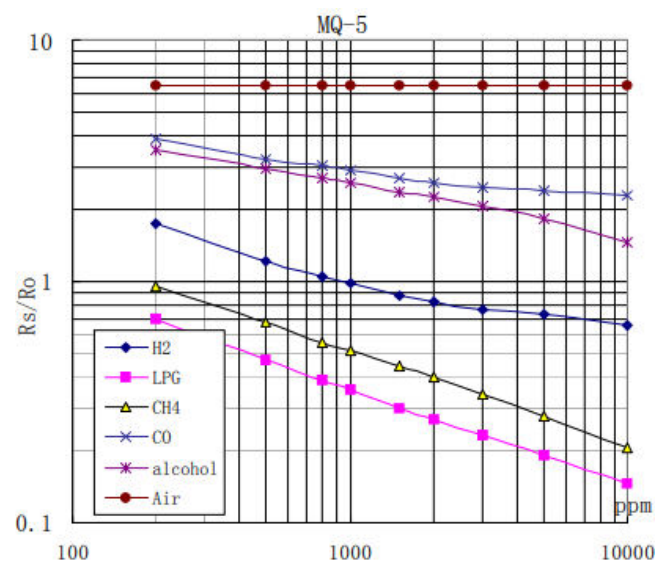

Gambar 6. Karakteristik sensor MQ-5 [5]. 
Tabel 1

Keterangan modul sensor gas MQ-5 [6]

\begin{tabular}{ccc}
\hline \hline No & Pin & Keterangan \\
\hline 1 & A Out & Analog keluaran \\
2 & D Out & Digital keluaran \\
3 & GND & GND \\
4 & VCC & Tegangan pengoperasian \\
\hline \hline
\end{tabular}

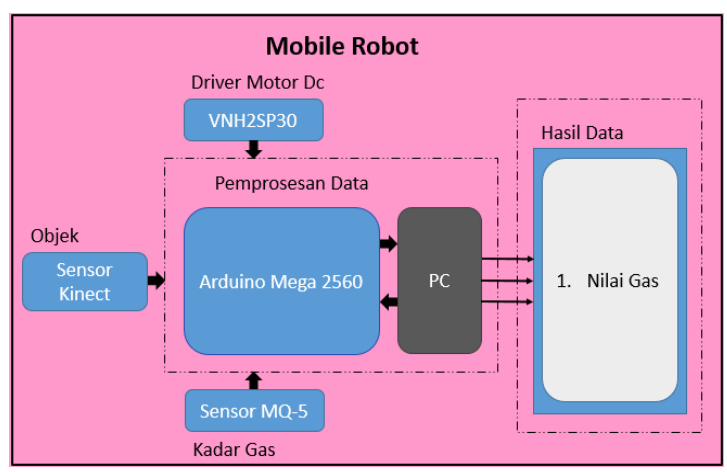

Gambar 7. Diagram blok arsitektur sistem mobile robot.

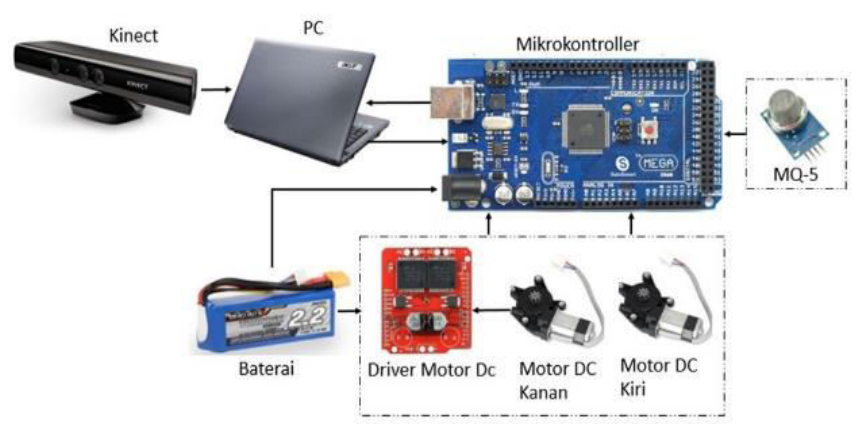

Gambar 8. Perancangan sistem perangkat keras.

\section{PERANCANGAN SISTEM}

\section{A. Arsitektur Sistem}

Blok diagram dari Gambar 7 merupakan penyederhanaan dari sistem mobile robot untuk mengindentifikasikan object yang mengandung bahan kimia berbahaya dengan memanfaatkan sensor kinect untuk mengenali object warna, mengetahui kandungan kadar gas menggunakan sensor mq-5 dan driver motor dc untuk mengentrol kecepatan roda sesuai dari data yang dikirim oleh sensor kinect dalam pembagian perbandingan pixel yang dikirimnya sebagai Tugas Akhir ini. Perancangan sistem ini bertujuan agar robot berjalan sesuai dengan perencanaan. Yaitu dapat berjalan sesuai dengan arah object dari inputan nilai HSV untuk dapat mengenali object warna yang kemudian akan berjalan menuju object, berhenti di depan object dan mendeteksi nilai kandungan kadar gas.

Pada Gambar 8 bagian mobile robot, terdapat beberapa bagian seperti, sensor, Pemrosesan data, dan kendali. Pada bagian sensor, terdapat dua bagian komponen yaitu sensor kinect untuk mengetahui warna object yang akan dijadikan target dan sensor mq-5 untuk mengetahui nilai kandungan kadar gas. Pada bagian pemprosesan data terdapat mikrokontroler untuk mengolah data masukkan dari sensor dan pc, yang nantinya akan digunakan untuk mengendalikan bagian kendali. Di mana bagian kendali ini terdapat aktuator yang berupa motor dc.

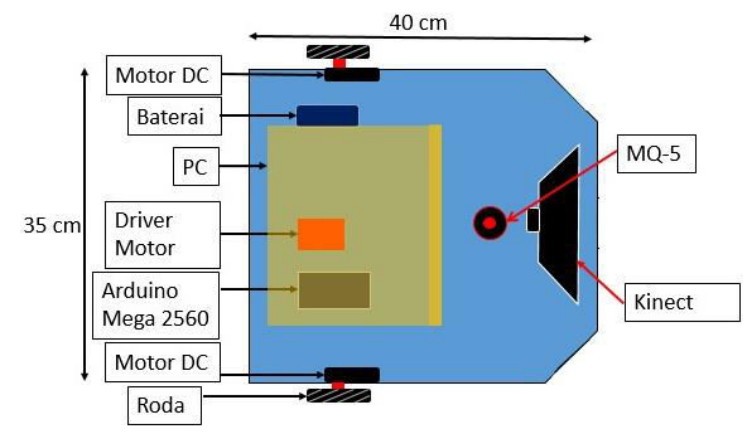

Gambar 9. Desain mekanik tampak atas.

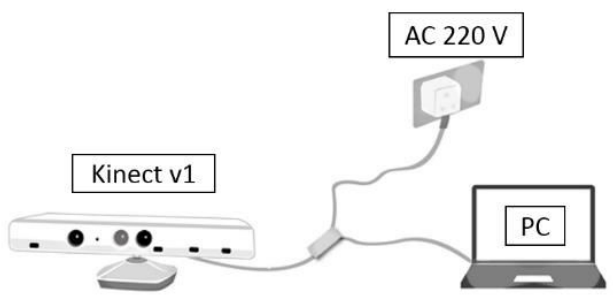

Gambar 10. Perancangan sensor kinect.

\section{B. Perancangan Desain Mobile Robot}

Pembutaan mekanik robot Gambar 9 menggunakan desain yang dibuat oleh penulis. Model mobile robot yang digunakan adalah mobile robot bergerak dengan motor dc 2 buah dengan dengan masing-masing menggunakan satu roda belakang kiri dan kanan kemudian bagian depan menggunakan satu buah roda yang dapat bergerak ke semua arah agar dapat bermanuver dengan baik.

\section{Perancangan Kinect}

Sensor kinect v1 merupakan komponen sensor yang menggunakan komunikasi serial yang dihubungkan usb sensor kinect pada pc. Pada jenis sensor kinect v1 sumber tegangan sensor yang masih terpisah dengan sumber tegangan pln ac 220 volt. Dapat dilihat pada Gambar 10 skema perancangan sensorr kinect v1.

\section{Perancanhan Sensor Gas MQ-5}

Modul sensor mq-5 mempunyai hasil keluaran berupa tegangan jika mendeteksi kadar gas butana di dalam udara. Pin keluaran dari sensor gas ini dihubungkan dengan pin A0 pada arduino uno, sumber tegangan supply 5 volt de dan ground. Sensor ini terdiri dari lapisan semikonduktor logam oksida yang terbentuk diatas sebuah substrat alumina pada sebuah sensing chip bersama dengan sebuah pemanas yang terintegrasi. Sensor ini bekerja berdasarkan perubahan resistansinya terhadap gas-gas tertentu termasuk asap. Tegangan untuk pemanas internal sangat penting. Beberapa sensor,menggunakan $5 \mathrm{~V}$ untuk pemanas, yang lain perlu $2 \mathrm{~V}$. Beberapa langkah sensor untuk pemanasan ialah dengan menggunakan program analogWrite ( ) fungsi. Pemanas perlu selama sekitar 3 menit sebelum pembacaan menjadi stabil. Pada Gambar 11 perancangan sensor MQ-5. 


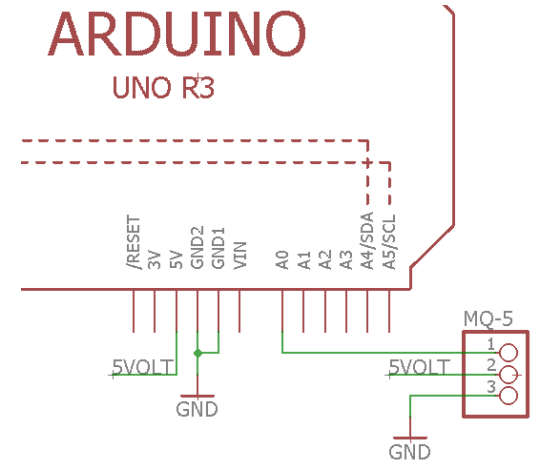

Gambar 11. Perancangan sensor MQ-5.

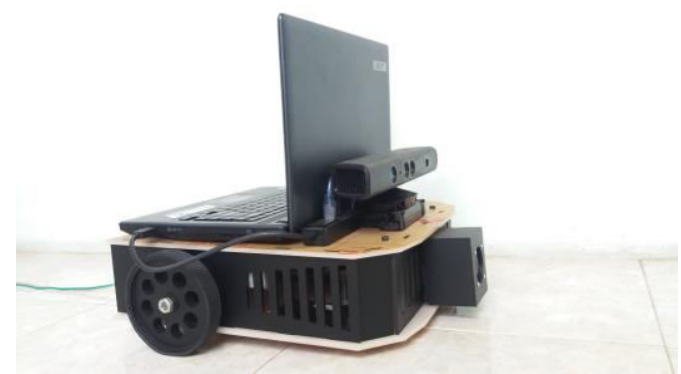

Gambar 12 Realisai desain sistem mobile robot.

\section{HASIL DAN DISKUSI}

\section{A. Hasil Realisasi Desain Mekanik Mobile Robot}

Desain mekanik mobile robot ini dimulai dengan perancangan perangkat keras kendali implementasi sensor kinect dengan penggabungan fungsi beberapa komponen seperti ditunjukkan Gambar 12 yaitu, sensor MQ-5, kinect v1, driver motor dc, motor dc 12 volt, baterai, mikrokontroler dan pc. Semua komponen penyusun dirangkai sedemikian rupa seperti yang ditunjukkan pada Gambar 12 desain mekanik tampak depan

Pembutaan mekanik robot menggunakan desain yang dibuat oleh penulis. Model mobile robot yang digunakan adalah mobile robot bergerak dengan motor dc 2 buah dengan dengan masing-masing menggunakan satu roda belakang kiri dan kanan kemudian bagian depan menggunakan satu buah roda yang dapat bergerak ke semua arah dapat bergerak dengan baik.

\section{B. Pengujian Pengolahan Citra}

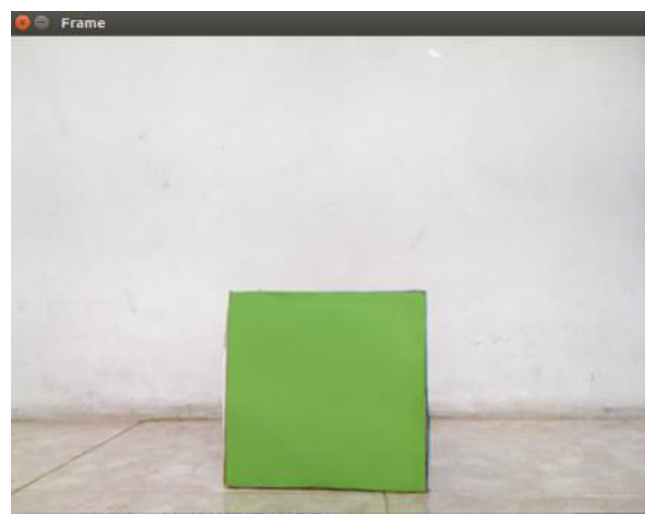

Gambar 13. Citra asli.

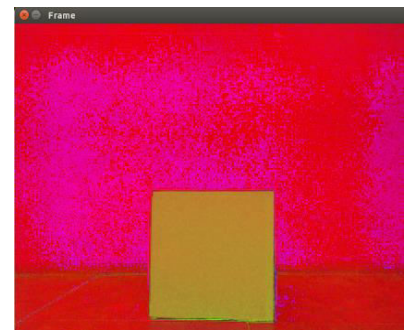

Gambar 14. Citra hasil pengubahan RGB ke HSV.

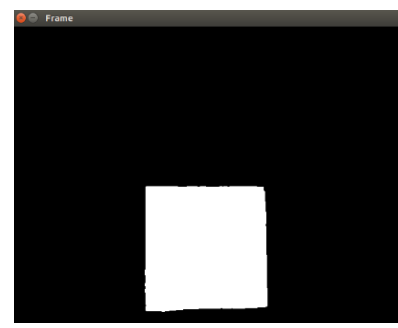

Gambar 15. Citra hasil filter dilantasi dan erosi.

Gambar 16. Citra hasil proses perolehan fitur.

Pengujian dilakukan dengan mengatur batas-batas nilai ambang yang digunakan untuk memperoleh citra biner yang memiliki warna pada citra RGB warna hijau dan warna hitam pada RGB warna selain hijau. Nilai batas ambang ini perlu diatur pada setiap lingkungan yang berbeda. Pada Gambar 13 menunjukan citra asli, Gambar 14 citra yang menunjukan hasil perubahan dari citra RGB ke HSV, Gambar 15 citra hasil filter erosi dan dilatasi, pada Gambar 16 Citra hasil proses perolehan fitur akhir yang ditambah dengan menampilkan nilai dari membacaan adc sensor MQ-5.

\section{Pengujian Mendapatkan Nilai Warna HSV}

Pada pengujian ini dilakukan untuk pengambilan nilai warna yang dicari di dapat terdeteksi dengan cara merubahubah nilai range hue, saturation dan value dengan hasil yang dapat dilihat pada Tabel 2. Contoh dalam pengambilan nilai mencari dapat dilihat di Gambar 17 yaitu mencari warna hijau pada Gambar 18 pada dengan nilai HSV adalah hue min 29 max 84, saturation min $86 \max 255$ dan value min 6 max 255 . Dengan percahayaan 2000 lux pada Gambar 19.

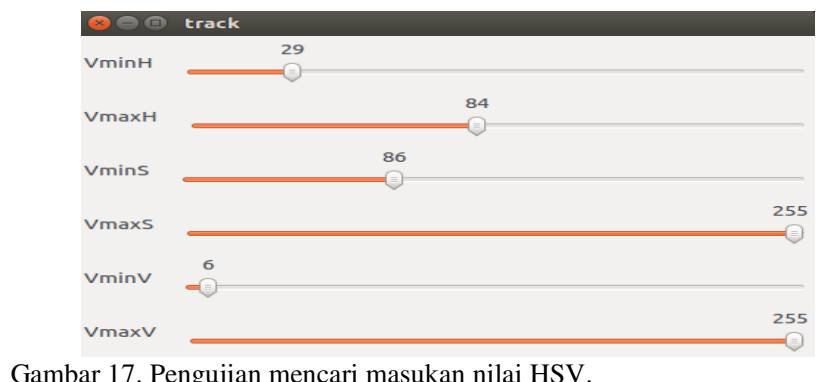




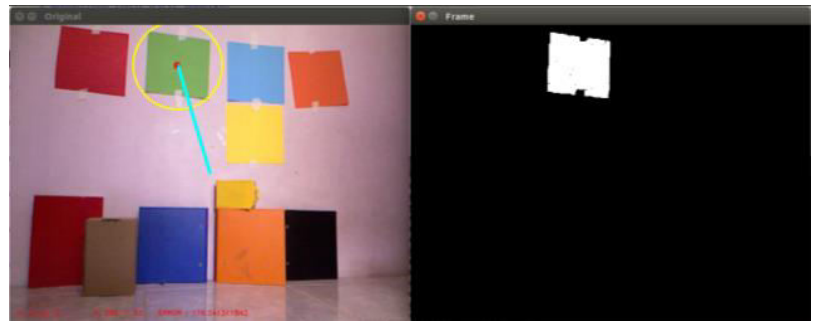

Gambar 18. Pengujian hasil mencari manual berwarna hijau dengan indikator percahayaan 2000 lux.

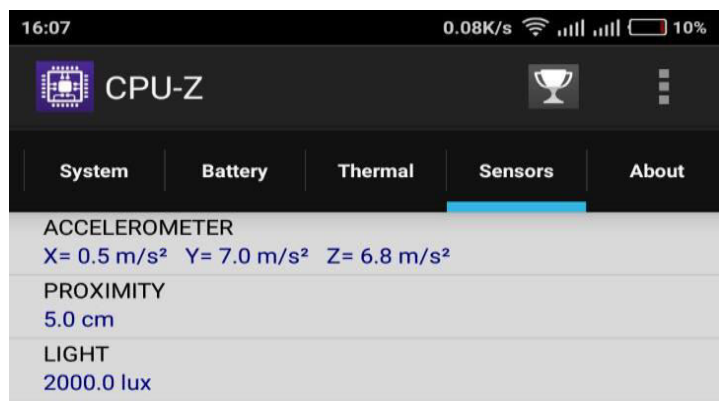

Gambar 19. Hasil pengujian percahayaan lux meter dengan menggunakan aplikasi handphone.

Tabel 2

Hasil mencari nilai color HSV

\begin{tabular}{llllllll}
\hline \hline No. & Color & Hmin & Hmax & $\begin{array}{l}\text { Smi } \\
\mathrm{n}\end{array}$ & Smax & Vmin & Vmax \\
\hline 1 & Biru muda & 102 & 110 & 86 & 255 & 6 & 255 \\
2 & Biru tua & 102 & 122 & 86 & 255 & 6 & 255 \\
& Hijau tua & 47 & 109 & 0 & 255 & 0 & 176 \\
3 & Hijau muda & 24 & 50 & 86 & 255 & 6 & 255 \\
4 & $\begin{array}{l}\text { Orangen } \\
\text { tua }\end{array}$ & 0 & 13 & 86 & 255 & 7 & 255 \\
5 & $\begin{array}{l}\text { Orangen } \\
\text { muda }\end{array}$ & 8 & 28 & 136 & 255 & 0 & 255 \\
& & & & & & \\
6 & Kuning & 19 & 28 & 136 & 255 & 0 & 255 \\
7 & muda & & & & & & \\
8 & Kuning tua & 17 & 34 & 115 & 255 & 10 & 216 \\
& Merah & 167 & 180 & 198 & 245 & 112 & 148 \\
9 & muda & & & & & & \\
12 & Merah tua & 171 & 180 & 158 & 255 & 0 & 255 \\
\hline \hline
\end{tabular}

D. Pengujian Pengukuran Jarak Menggunakan Depth Sensor Kinect

Pada pengujian jarak menggunakan Depth sensor kinect dapat diihat pada Gambar 4.9 yaitu implementasi pengujian sensor depth pada objek yang berupa semua objek benda. Pengujian ini dilakukan untuk mengetahui jarak minimal dan maksimal depth sensor kinect dapat pendeteksi objek benda di depanya. Hasil dari pengukuran dari depth sensor kinect kemudian dibandingkan dengan melakukan pengukuran manual dengan menggunakan alat ukur penggaris. Dapat dilihat hasil data dari depth sensor kinect dengan objek benda yang ada di depannya pada hasil Gambar 20. Jarak perubahan diambil setiap $10 \mathrm{~cm}$ terhadap setiap langkah hasil pembacaan.

Dari hasil yang didapat pada Gambar 21 mengetahui jarak minimal depth sensor kinect bekerja adalah $40 \mathrm{~cm}$ kemudian jarak maksimal depth sensor kinect mengetahui jarak adalah $400 \mathrm{~cm}$. Dan hasil antara pengukuran manual dengan pengukuran menggunakan depth sensor kinect presisi dan akurat.

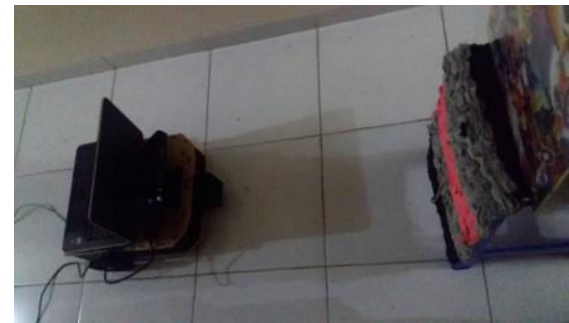

Gambar 20. Implementasi pengujian sensor depth pada objek.

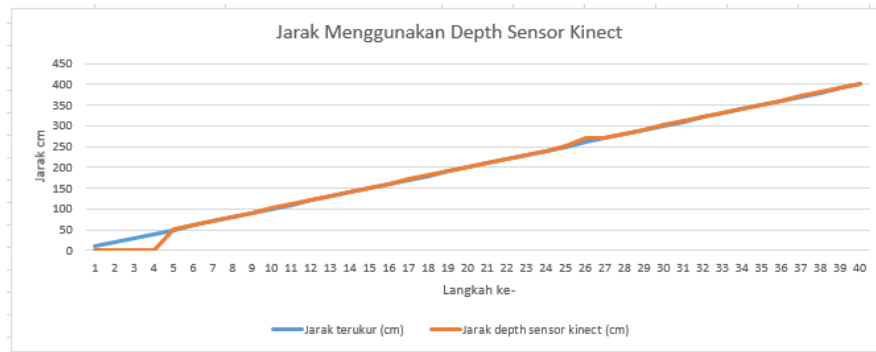

Gambar 21. Grafik pengujian jarak menggunakan depth sensor kinect.

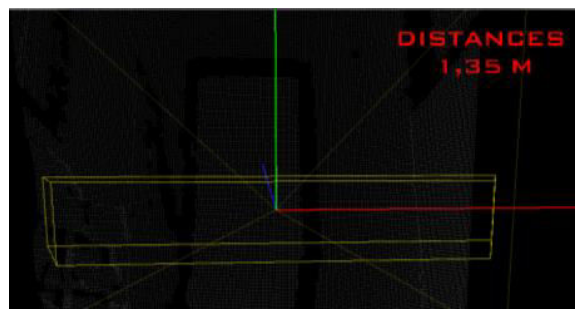

Gambar 22. Interface depth sensor.

Pada Gambar 22 adalah interface depth sensor hasil pengujian tampilan dari pembacaan depth sensor kinect dalam mengetahui jarak membacaan antara sensor kinect terhadap objek yang ada di depannya.

\section{E. Pengujian Sensor MQ-5}

Pada tahap ini pengujian sensor MQ-5 berupa gas isobutane. Kalibrasi yang dilakukan tanpa adanya zat iso-butane pada area tempat sensor tersebut bekerja. Kalibrasi sensor dilakukan dengan menempatkan kadar gas ke sensor MQ-5 pada area tempat kerja sensor tersebut. Sensor diletakan pada area dengan kadar udara netral dari gas iso-butane untuk mendapatkan nilai Ro. Dilakukan di dalam ruangan dengan suhu $25^{\circ} \mathrm{C}$, kecepatan kipas Air Conditioner pada skala 3 (Panasonic Eco Smart ruang 402). Data hasil pengujian respon sensor kemudian berupa perubahan perbandinagn Rs/Ro, Ppm dan perubahan konsentrasi gas terhadap waktu $t(s)$ dapat di lihat pada Gambar 24 dan 25. Dengan jarak sumber tabung gas iso-butane terhadap sensor MQ-5 adalah 1 meter pada Gambar 23. Pengujian ini berpengaruh terhadap waktu dapat terlihat ketika dibuat grafik ketika sensor MQ-5 mendeteksi gas isobutane. Pada Gambar grafik 25, dari waktu yang berpengaruh terhadap kadar gas dari pembacaan nilai RS/Ro. Ppm merupakan kadar gas yang terdeteksi, t merupakan waktu dalam satuan detik. Dapat dilihat dari grafik Gambar 24, dari t saat $14 \mathrm{~s}$ hingga t saat $38 \mathrm{~s}$. Gambar 6 grafik dari karakteristik sensor MQ-5 dapat disimpulkan bawah ketika adanya kadar gas iso-butane maka nilai Ppm semakin besar. 


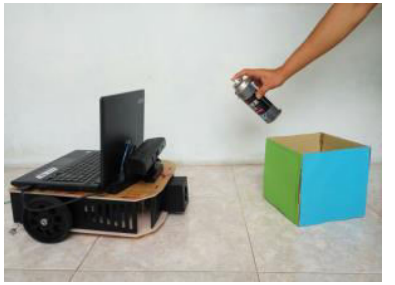

Gambar 23. Pengujian mobile robot dengan gas iso-butane.

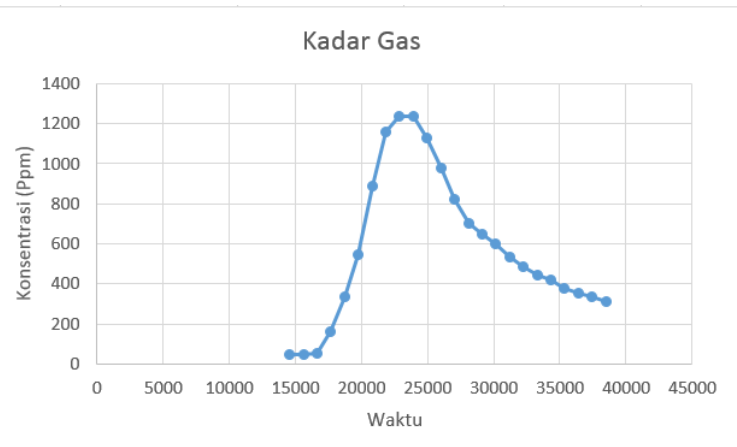

Gambar 24. Grafik hasil data sensor gas MQ-5 ppm terhadap waktu.

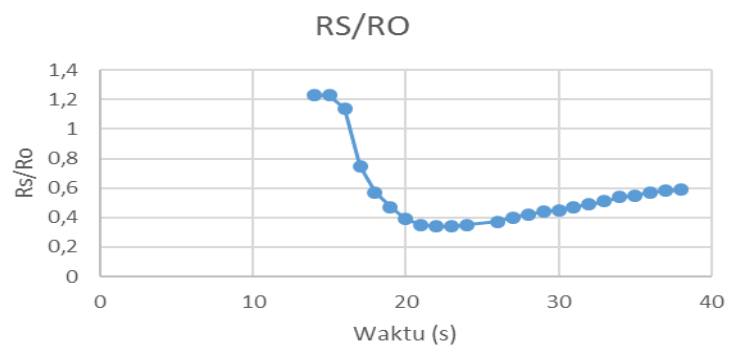

Gambar 25. Grafik hasil data sensor gas MQ-5 Rs/Ro terhadap waktu.

\section{F. Pengujian Integrasi Sistem Mobile Robot}

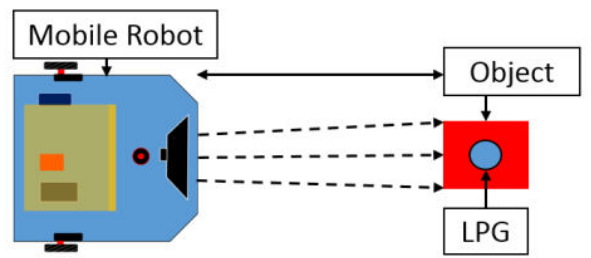

Gambar 26. Algoritma sistem mobile robot pada posisi objek di depan.

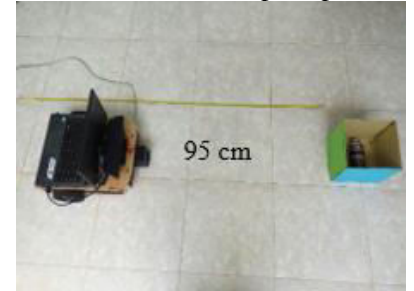

Gambar 27. Hasil implementasi algoritma sistem mobile robot pada posisi objek di depan.

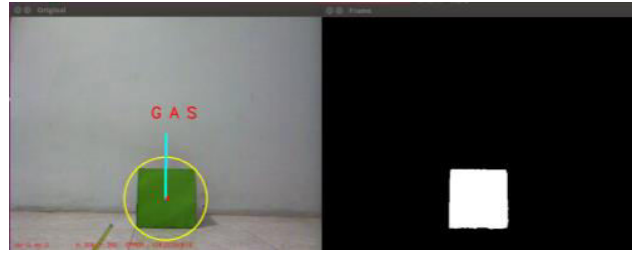

Gambar 28. Citra hasil filter dilatasi dan erosi dan citra hasil proses perolehan fitur tampak depan.

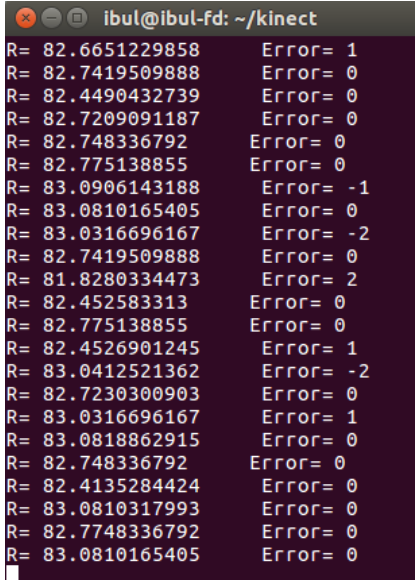

Gambar 29. Hasil data error dari deteksi objek tampak depan.

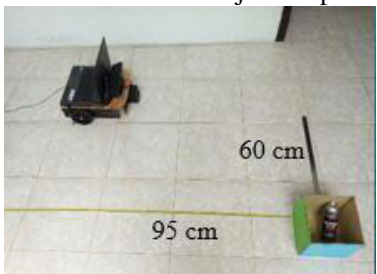

Gambar 30. Hasil implementasi algoritma sistem mobile robot pada posisi objek di kanan.

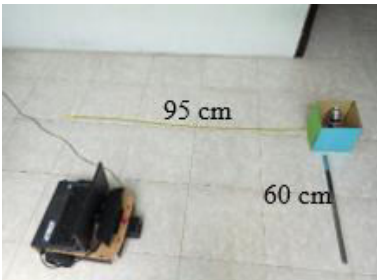

Gambar 31. Hasil implementasi algoritma sistem mobile robot pada posisi objek di kiri.

Pada pengujian ini adalah pengujian yang dilakukan pada sistem yang sudah terintegrasi untuk kemudian diuji pada ruangan lapangan tertutup. Pengujian ini dilakukan ruangan kost dengan panjang $4 \times 8$. Dengan pengujian pertama yaitu Gambar 26 simulasi yang akan dijadikan algoritma posisi objek didepan mobile robot dan Gambar 27 hasil implementasi dari mobile robot sebenarnya dengan objek yang berwarna hijau. Dengan jarak $95 \mathrm{~cm}$ dari objek terlihat pada Gambar 27 dengan alat ukur meteran kain. Gambar 28 menunjukan citra dari hasil filter dilatasi dan erosi. kemudian pada Gambar 29 citra hasil proses perolehan fitur tampak depan dengan sumbub $\mathrm{x}$ ditengah dengan data error kurang lebih 0 artinya hasil implementasi sensor kinect dengan objek pada posisi didepan terbaca dengan hasil yang tepat. Pengujian kedua adalah posisi dikanan dan kiri dapat dilihat pada Gambar 30 dan Gambar 31 pada hasil pengujian ini mobile robot dapat berjalan sesuai dengan objek target berwarna hijau yang terdeteksi.

\section{KESIMPULAN}

Berdasarkan data hasil pengujian dalam pembuatan tugas akhir ini, dapat ditarik kesimpulan sebagai berikut :

1. Hasil percobaan kamera sensor kinect ketika mendapatkan nilai objek warna hijau dengan metode HSV adalah hue 29 - 84, saturation 86 - 255, value 6 255 dengan percahayaan ruangan 2000 lux, kesalahan 
nilai warna objek hijau dengan percahayaan ruangan 80 lux.

2. Pada pengukuran jarak menggunakan depth sensor kinect yang dilakukan, didapat bahwa minimal kinect adalah $40 \mathrm{~cm}$ dalam membaca objek dan maksimanl $400 \mathrm{~cm}$.

3. Kecepatan dan arah angin dapat mempengaruhi nilai pembacaan sensor gas MQ-5 ini. pembacaan gas stabil ketika adanya kadar iso-butane pada hasil data Tabel 4.3 bahwa nilai Ppm 1129,27 dan ketika tidak adanya kadar gas iso-butane nilai Ppm 45,14. maka sesuai dengan Gambar 2.7 grafik dari karakteristik sensor MQ-5 dapat disimpulkan bawah ketika adanya kadar gas iso-butane maka nilai Ppm semakin besar. Pada sensor gas dapat memetakan kadar gas suatu lokasi kurang lebih 1 meter dalam keadaan ruang hampa.

\section{DAFTAR PUSTAKA}

[1] S. Riyanta, "Prediksi dan Analisis Ancaman Terorisme Tahun 2017 di Indonesia," detiknews. .

[2] N. Zhigang and W. Lu, "Hazardous Gas Detecting Method Applied in Coal Mine Detection Robot," in 2011 Third International Conference on Measuring Technology and Mechatronics Automation, 2011, pp. 308-311.

[3] Y. Izza and B. B. Murti, "Sistem Kontrol Gerak Lengan Robot Menggunakan Metode Isyarat Gerak Tubuh Dengan Sensor Kinect,” Yogyakarta, 2016.

[4] A. Rachmanwan, H. Kusuma, and R. Mardiyanto, "Penentuan Posisi Robot Sepak Bola Beroda Menggunakan Rotary Encoder Dan Kamera," Surabaya, 2017.

[5] W. Rafael and C. Gonzalez, Digital Image Processing, 2nd ed. New Jersey: Prentice Hal, Inc, 2002.

[6] R. A. Wibobo, M. Rivai, and Suwito, "Implementasi Autonomous Navigation Robot Menggunakan Global Positioning System (GPS) Untuk Pemetaan Kadar Gas Berbahaya,” Surabaya, 2017. 